\title{
Modern strategies for regulating the motor activity of preschool and school age children in the educational space
}

\author{
Voloshina L.N. ${ }^{1 \mathrm{AD}}$, Kondakov V.L. ${ }^{2 \mathrm{ACD}}$, Tretyakov A.A. ${ }^{3 \mathrm{DE}}$, Kopeikina E.N. ${ }^{2 \mathrm{BCD}}$, Cretu M. ${ }^{4 \mathrm{BCD}}$, Potop V. ${ }^{\text {BCD }}$ \\ ${ }^{1}$ Faculty of Preschool, Primary and Special Education, National Research University Belgorod State University, \\ Russia \\ ${ }^{2}$ Faculty of Physical Culture, National Research University Belgorod State University, Russia \\ ${ }^{3}$ Department of Physical Training, Putilin Belgorod Law Institute of Ministry of the Interior of Russia, Russia \\ ${ }^{4}$ Faculty of Science, Physical Education and Informatics, University of Pitesti, Romania \\ ${ }^{5}$ Faculty of Physical Education and Sport, Ecological University of Bucharest, Romania
}

Authors' Contribution: A - Study design; B - Data collection; C - Statistical analysis; D - Manuscript Preparation; E - Funds Collection.

\begin{tabular}{|c|c|}
\hline \multicolumn{2}{|l|}{ Abstract } \\
\hline Purpose: & $\begin{array}{l}\text { the systematization of modern strategies for regulating the motor activity of preschool and school-age } \\
\text { children. The criteria for assessing motor activity taking into account the individual characteristics of children } \\
\text { and sociocultural conditions are considered. The adaptive strategy of regulation of the motor activity of a } \\
\text { growing person in modern educational space is substantiated. }\end{array}$ \\
\hline Material: & $\begin{array}{l}10 \text { theses and more than } 80 \text { papers published in specialized journals of Russia, Ukraine, Kazakhstan, Belarus } \\
\text { were analyzed. In the article is used quantitative approach, which has research and descriptive character. This } \\
\text { approach includes methods for examining documents. The identification of studies over the past } 50 \text { years } \\
\text { has been carried out. The analysis of normative program-methodological materials, educational standards, } \\
\text { exemplary educational programs and the results of their own research was carried out. These studies } \\
\text { substantiated various approaches to regulating and forming positive dynamics of motor activity in preschool } \\
\text { and school-age children. }\end{array}$ \\
\hline Results: & $\begin{array}{l}\text { Three strategies for regulating motor activity were identified: biological, value-social and biosocial (adaptive). } \\
\text { Their compliance with the level of scientific and methodological knowledge and domestic experience is } \\
\text { established. The limiting factors have been established and ways of transforming the system of physical } \\
\text { education at different levels of education have been concretized. The modern adaptive strategy of regulation } \\
\text { of the motor activity of preschool children and younger schoolchildren is substantiated. The expediency of } \\
\text { its introduction into the educational process is shown. This creates a favorable environment for the physical } \\
\text { development of children. }\end{array}$ \\
\hline Conclusions: & $\begin{array}{l}\text { The adaptive system for regulating motor activity should take into account: the interests and opportunities } \\
\text { of children at all levels of the educational system; regional sports traditions; sociocultural and climatic } \\
\text { conditions. It is extremely important to recreate the playing space of childhood. This contributes to the } \\
\text { formation of an active position in relation to the physical culture of the individual. }\end{array}$ \\
\hline Keywords: & $\begin{array}{l}\text { Motor activity, physical education, regulatory strategies, preschool institutions, school, optimization, } \\
\text { adaptation strategy. }\end{array}$ \\
\hline
\end{tabular}

\section{Introduction}

In recent years, the environment for modern children has changed. In place of the exciting mobile games, came no less exciting - computer games. In the preferences and interests of preschool children and younger schoolchildren, there have been significant changes in the structure of their free time $[1,2]$.

In the development of modern children, the following phenomena are observed: hyperactivity; hypodynamia; increase the influence of psycho-emotional stress on the body. Such phenomena slowly and imperceptibly affect the children's organism. They cause disturbances in the balance between the body and the natural and social environment. Also lead to serious diseases of the cardiovascular system and metabolic disorders. Their negative impact on the musculoskeletal system (MSS) is noted. According to the World Health Organization

\footnotetext{
(c) Voloshina L.N., Kondakov V.L., Tretyakov A.A., Kopeikina

E.N., Cretu M., Potop V., 2018
}

doi:10.15561/18189172.2018.0208
(WHO), 80\% of the world's population is affected by various MSS disorders. [3-5].

Reduction of motor activity and muscular effort depends on many factors. This is determined by the inactive way of life of modern children in highly developed countries $[6,7]$. The prevalence of hypodynamia in young children is associated with: the destruction of the playing space of childhood; enthusiasm for digital or virtual environments; change of interests; the emergence of a variety of forms of leisure, excluding motor activity; strengthening the orientation of the educational process in educational institutions [8-10].

Thus, an increasing number of children are in conditions of hypodynamia. The biological need for movement of children in the modern educational space of Russia is satisfied only by $60 \%$. Similar trends are observed in other countries [11-13].

The state of hypodynamia is characterized by a decrease in the functions of all organs and systems, a disorder of their interrelations in the body. Biological 
reliability and stability of the human body is reduced with significant functional loads and exposure to adverse environmental factors. These limits the working capacity of the organism [14-16]. With regard to children, we can only talk about relative hypodynamia. It is known that a certain minimum of motor activity is realized by the child in independent motor activity. Inadequate motor activity adversely affects many functions of the growing organism. It can serve as a pathogenetic factor in the onset and progression of a number of diseases [17-19]. Studies show that insufficient motor activity of children adversely affects the development and functional state of the cardiovascular system [20, 21]. Many preschoolers and schoolchildren are distinguished by good physical development. They also have an inadequate performance of some functions, a decrease in physical performance. All this is due to pronounced hypodynamia [22, 23]. Thus, children of preschool and school age need optimal motor activity. It must satisfy: the biological need of a growing organism in movements; promote physical development, high efficiency, the formation of a variety of physical qualities and skills [24, 25].

The problem of hypodynamia acquires a social character. Its successful solution can be achieved only through comprehensive efforts of the state, educational and public organizations, teachers, parents and children themselves. We believe that at the present stage of development of preschool and primary education, one more problem - the problem of hyperactivity - requires attention.

According to statistics, hyperactivity is diagnosed in almost $18 \%$ of children. This is much more common in boys than in girls [9, 26]. In hyperactive students of lower grades, the nervous system can not cope with the increased demands of mental and physical exertion. Therefore, in the school there is a significant deterioration in their condition: the inability to concentrate attention; inability to sit in one place for a while; imbalance; low self-esteem; short temper; headache; nervous tic; the emergence of a variety of phobias. At the same time, hyperactive senior pupils have a perfectly developed intellect. But they differ in poor performance $[18,20]$. The reasons lie in inattention. High school students are distinguished by impulsiveness, inability to assess the consequences of acts, aggressiveness. Such schoolchildren find it very difficult to find common language with peers and are prone to various conflicts [18].

At present, scientific and practical importance has an assessment of the existing motor activity of modern preschool children and schoolchildren. It is important to define: scientific approaches and improving the principles of rationing activity; minimum motor activity and ways to achieve it, which is necessary to ensure the harmonious physical development of the child.

There is a contradiction between the need for society to preserve and strengthen children's health and the lack of motor activity and regulation of hyperactivity in preschool children and schoolchildren. All this confirms the relevance of the problem of regulating the motor activity of children at the social, pedagogical, scientifictheoretical and scientific-methodical level. Optimal motor activity should contribute to the harmonious development of the child in the broadest sense of the word. Such activity should optimally influence physical and mental development, strengthen health, ensure high performance in subsequent periods of human life. Children need to create conditions in which they can fully satisfy the biological need for movement and improve their general physical training. To this end, a sufficient volume of organized and independent forms of motor activity should be included in the children's mode of life.

The aim of the study is to determine the leading strategies for regulating the motor activity of preschool and school children in the modern educational space.

\section{Material and methods.}

Participants and parameters. 10 theses and more than 80 papers published in specialized journals of Russia, Ukraine, Kazakhstan, Belarus and other countries were analyzed.

Study Design: in the paper is used quantitative approach, which has research and descriptive character. This approach includes methods for examining documents.

Data collection: identification of studies for the last 50 years has been carried out $[6,10,27]$. The analysis of normative program-methodological materials, educational standards, exemplary educational programs and the results of their own research was carried out [28, 29]. These studies substantiated various approaches to regulating and forming positive dynamics of motor activity in preschool and school-age children [22, 23, 30]. In most of the works, the main means of regulating motor activity were exercise and mobile games [9, 31]. Working with the material of the studies made it possible to distinguish three strategies for regulating motor activity. Deep analysis of modern strategies for regulating the motor activity of preschool and school age children allows to: identify their compliance with the level of scientific and methodological knowledge and domestic experience; establish limiting factors; concretize the ways of transforming the system of physical education at different levels of education. This approach can be considered a significant evidence of the justification of the modern adaptive strategy for regulating the motor activity of preschool children and junior schoolchildren. The expediency of introducing such a strategy into the educational process is justified by the creation of a favorable environment for the physical development of a growing person.

Data analysis: articles and dissertations were analyzed and classified according to their content and type.

\section{Results.}

The rapid progress of the spectrum of human sciences in the past century put the issue of a new paradigm of thinking on the agenda. Such a paradigm would allow us to rethink our ideas about the mechanisms governing the motor activity of a person. Such mechanisms represent an integral system in all the diversity of interaction between 
the individual and social sides.

It is known that movement is the basis of all the physiological functions of the human body. This is manifested in interaction with the external environment $[15,23]$. Therefore, movement is an obligatory component of all types of homeostasis. Movement should be characterized by the consistency of its characteristics. Therefore, the full development of the children's organism is possible only on condition of maximum satisfaction of their biological need for movement [18, 27]. If this condition is not met, then defects in physical development inevitable appear. There is also an obvious or hidden pathology of individual functional systems. Already at this stage of age development, hypokinesia becomes a significant risk factor in the development of various diseases. Therefore, before 7-8 years of age, the level of motor activity should be consistently and intensively increased $[4,5]$. At the stage of early growth (3-7 years) there is a process of development of coordination mechanisms of vital activity and all functional systems. To improve them, the motor potential is needed, which accumulates in previous years [5, 6].

Let us turn to an analysis of the biological strategy for regulating the motor activity of a growing person. It laid the idea of N.A. Bernstein [32] and I.A. Arshavsky [33]. The authors defined a new understanding of the vital activity of the organism. It is seen as an active and purposeful system: the process of life is an active interaction with this environment.

The energy rule of skeletal muscles is formulated. According to this rule: the state and development of the organism in each age period is determined by the functioning of the muscular system; every movement is a factor in the induction of excess anabolism. As a result, growth and development of the organism becomes possible. This rule operates throughout the ontogenesis, beginning with the embryonic period.

Other studies confirm the need for a valuesocial strategy for regulating motor activity [3, 18]. Understanding the socio-biological inheritance of the healing effects of physical culture influences the reorientation of public consciousness in the field of physical culture. This contributes to improving the health of children $[18,19]$. Important role in the upbringing of the younger generation is given to the family. The role of the family is determined by the independence of its impact on the development of children. This allows you to take into account the characteristics of the child, which parents know much better than other caregivers [16].

The social environment has a significant influence on the formation of various activities. The physical activity of teachers, parents and friends can influence the increase and decrease in the level of physical activity of children. The targeted impact of the social environment is aimed at: intensifying the efforts of the child's personality; the solution of problems arising before it; creation of conditions for improving motor activity; initiation of their regular physical activity.
The basis of the formation of physical activity of children is the need-motivational processes. They allow children to achieve the goals of physical improvement and to strengthen mental and physical health. Such processes contribute to the achievement of social wellbeing and improving the emotional state of children. [22, 30]. The same thing happens with studies: the acquisition of physical culture and sports knowledge should be seen as a means to make your physical activity more effective. Physical exercises begin to serve as a means of acquiring knowledge, skills, health, and development of a personality [28, 34].

Analysis of modern preschool education programs has shown that in most of them actual tasks are set for the development of the child's motor activity. They reflect modern trends in the physical education of preschool children: stimulating physical activity at the expense of the social determinant. Such socially-determined physical culture motives and needs provide a stable motivation for motor activity $[15,18]$. The developed mechanisms and means for implementing these tasks for children of younger preschool age are effective only in cooperation with an adult.

One of the most important conditions for the mental and physical health of children in this age period is rational socialization. It is also important to improve the skills of adaptation to the changing conditions of the social environment. The child develops when he himself is active and interacts with the world. The nature of this activity is determined by the subjectively free relation of personality.

Athletic and sporting motives and needs, knowledge and skills are a specific content of motor activity. This is acquired through social determination and allows the child to become the creator of his bodily nature. This provision we will take into account when developing criteria and indicators of motor activity.

At the heart of the pedagogical component of the valuesocial strategy for regulating motor activity lies a number of studies by Russian scientists [3, 23]. In the work of L.K. Sidorov showed that in the methodology of building a system of physical education, the foundation of the state of motor need will be the fundamental principle: the need for physical training will be assessed at the subconscious level [31]. Only such a level of the formation of the motor need will allow to solve successfully all the problems facing physical education.

We can state that the systemic, activity-based and humanistic approaches become the answer to the vital questions of optimizing the motor activity of the child.

In domestic studies, various methods of measuring motor activity are reflected: for time costs (per day, per week); by the number of locomotion performed per day (pacing); on energy costs (in calories or Joules per unit of time).

It is important to obtain reliable and objective information that allows us to judge the proper norms of the motor activity of various social groups of the 
population. This is especially important for modern youth. It is important to understand the influence of factors that determine the storyline of their behavior in everyday life. The methods of questioning (polling, ranking, observation) will help objectively evaluate the optimality of the motor regimes of young people.

In the field of physical education in programs and technologies should be taken into account the sociopedagogical factor. The most significant criterion is the degree of fulfillment of the social order. Management decisions seem reasonable only from the standpoint of their social effectiveness and expediency.

All these makes it necessary critically analyze the approaches, principles and technologies for regulating the motor activity of children of preschool and school age that are actually working in practice. Such approach will allow to reveal their conformity to the level of scientific and methodological knowledge. Also, it will allow to establish limiting factors and to specify ways of transformation.

\section{Discussion.}

Our analysis of the regulation of the motor activity of preschool children and junior schoolchildren proves the existence of a problem situation. This issue is given much attention. Scientists offer different approaches to regulating the motor activity of children. Optimization of the motor activity of children requires an appropriate analysis of modern curricula, technologies, health systems. Some authors have substantiated approaches to the organization of physical culture and sports in general educational institutions. The authors take into account the peculiarities of working with children of preschool age [30].

In other studies, great importance is attached to the formation of the physical culture of the personality of children through joint activities with parents [22]. The authors disclose the tasks of intellectual development of children in physical education. They determine the content and direction of activity of children of preschool and school age by means of physical culture. Also, the approaches for solving the above problems are substantiated $[22,23]$. Other authors integrate intellectual and social activities into the formation of the need for motor activity [24, 31].

These campaigns uncover various aspects of the realization of the motor potential of children. They point out the shortcomings of the educational process in physical culture and social environment. This allows you to form the needs of children, motives, knowledge and skills.
The problem of regulating the motor activity of a growing person is significant for specialists in the field of physical culture and medicine in Poland, Sweden, Ukraine, Australia and in other countries of the world [13, 35-38]. The analysis of scientific research on the problems of regulating the motor activity of children allows to study all aspects of the implementation of this activity. For this we propose an adaptive approach. This approach takes into account the internal components of regulation. Also takes into account the external aspects of stimulating motor activity in the social, psychological, and biological environments.

\section{Conclusions.}

Analysis of the results of the studies allows us to identify three areas in the definition and regulation of motor activity. At the heart of each of them is one advantageous factor. This fact determines the level and conditions of motor activity. We have identified three strategies for regulating motor activity: biological, valuesocial and biosocial (adaptive).

An analysis of the studies on this problem points to the lack of a holistic strategy for the formation of an active motor regimen of children. The biological needs, desires and interests of children are not taken into account. Do not take into account the social environment in which children develop. The lack of a pedagogical system and the technology of its implementation make it very difficult to achieve the goal of raising healthy children.

All of the above indicates the need to create an appropriate system for regulating the motor activity of children. The basis of such a system is the adaptation approach. This approach combines modern ideas to regulate motor activity. This will allow to form an active position of children and regulate the motor activity at the biological level. This approach allows at the pedagogical level to: fill the lack of activity; direct excessive activity towards specific goals. This will ensure the adaptation of children to the educational process and social conditions. The adaptive system of regulation of motor activity should take into account: wishes and opportunities of children; regional sports traditions at all levels of the educational system. It is extremely important to recreate the social environment and the playground of childhood, which contribute to the formation of an active healthy position in relation to the physical culture of the individual.

\section{Conflict of interest.}

The authors state that there is no conflict of interest. 


\section{References:}

1. Harrison M, Burns CF, McGuinness M, Heslin J, Murphy NM. Influence of a health education intervention on physical activity and screen time in primary school children: 'Switch Off Get Active’. J Sci Med Sport, 2006;9:388-94.

2. Palmer S, Graham G, Elliot E. Effects of a web-based health promotion on fifth grade children's physical activity knowledge, attitudes and behavior. Am J Health Educ, 2005;36:86-93.

3. Komkov AG, Lubysheva LI. Sociological foundations of a healthy lifestyle and physical activity of schoolchildren. Fizicheskaia kul'tura: vospitanie, obrazovanie, trenirovka, 2003;1:40 - 46. (in Russian)

4. Prokofeva VN, Kuznetsova VI. Physical preparedness and somatic features of the organism of preschool children. Teoriia i praktika fizicheskoj kul'tury, 2009;8:59-63. (in Russian)

5. Ericsson I. Effects of increased physical activity on motor skills and marks in physical education: an intervention study in school years 1 through 9 in Sweden. Physical Education \& Sport Pedagogy, 2011;16(3): 313-329.

6. Minnikaeva NV. Playing activity in the motor mode of the day of senior preschool children as a means of forming the physical culture of the individual. Cand. Diss. Omsk; 2009. (in Russian)

7. Kriemler S, Zahner L, Schindler C, Meyer U, Hartmann T, Hebestreit H, Brunner-La Rocca HP, van Mechelen W, Puder JJ. Effect of school based physical activity programme (KISS) on fitness and adiposity in primary schoolchildren: cluster randomised controlled trial. BMJ, 2010; 340:785.

8. Straczynska A, Kruczynski J, Radziminska A, Weber-Rajek M, Lulinska-Kuklik E, Goch A. The positive role of kinesio taping in adjunctive therapy of static plano-valgus feet in children between the ages of 5 and 7. Baltic Journal of Health and Physical Activity. 2017;9(2):89-97.

9. Lidgieva GN. The maintenance and the organization of process of development by children of 3-6 years of intellectual values of physical training. Cand. Diss. Krasnodar; 2005. (in Russian)

10.Pozdnyakova GP. Motor activity as a condition and factor of development of subjectivity of children of preschool age. Cand. Diss. Moscow; 2006. (in Russian)

11.Haerens L, De Bourdeaudhuij I, Maes L, Cardon G, Deforche B. School-based randomized controlled trial of a physical activity intervention among adolescents. $J$ Adolesc Health, 2007; 40:258-65.

12.Jurg ME, Kremers SP, Candel MJ, Van der Wal MF, De Meij JS. A controlled trial of a school-based environmental intervention to improve physical activity in Dutch children: JUMP-in, kids in motion. Health Promot Int, 2006; 21:32030.

13.Wen LM, Fry D, Merom D, Rissel C, Dirkis H, Balafas A. Increasing active travel to school: are we on the right track. A cluster randomized controlled trial from Sydney, Australia. Prev Med, 2008; 47:612-8.

14.Weber-Rajek M, Radziminska A, Slominski K, LulinskaKuklik E. Evaluation of the Effectivenness of Sonotherapy in the Treatment of Chronic Pain Syndromes of the Lumbosacral Spine - Pilot Study. Acta Balneologica. 2017;59(2):104-110.

15.Komkov AG, Antipova EV. Formation of physical activity of children and adolescents as a social and pedagogical problem. Teoriia i praktika fizicheskoj kul 'tury, 2003;3:5-8. (in Russian)

16.Pasechnik LV. Optimization of motor activity as a condition of health preservation. Teoriia i praktika fizicheskoj kul'tury,
2007;11:91-92. (in Russian)

17.Zarebska A, Jastrzebski Z, Moska W, Leonska-Duniec A, Kaczmarczyk M, Sawczuk M, et al. The AGT Gene M235T Polymorphism and Response of Power-Related Variables to Aerobic Training. Journal of Sports Science and Medicine. 2016;15(4):616-624.

18.Krivolapchuk IA. Optimization of the functional state of children and adolescents in the process of physical education. Grodno: Gr. PG; 2007. (in Russian)

19.Lubysheva LI. Modern value potential of physical culture and sports and ways of its development by society and personality. Teoriia i praktika fizicheskoj kul 'tury, 1997;6:10 15. (in Russian)

20.Islamov NM, Kiamova NI, Kirillova TG. Ontogenetic features of the growing organism: textbook for students. Naberezhnye Chelny: KamGAFKSiT; 2009. (in Russian)

21.Doroshenko EY, Svatyev AV, Iermakov SS, Jagiełło W. The use of cardio training facilities in training 7-9 year old judo athletes. Archives of Budo Science of Martial Arts and Extreme Sports. 2017;13.

22.Gaidalina II. Increasing the level of physical education of children 5-6 years old on the basis of intensification of joint physical and sports activities with parents. Cand. Diss. Krasnodar; 2010. (in Russian)

23.Golybeva GN. Formation of the active motor mode of the child (up to 6 years) by means of physical education in the main periods of adaptation to environmental conditions. Dokt. Diss. Moscow; 2008. (in Russian)

24.Pravdov MA. Integration of the motor and cognitive activity of children in physical education in pre-school educational institutions. Dokt. Diss. Shuya; 2003. (in Russian)

25.Kriventsova I, Pashkevych S, Iermakov S, Bartík P, Michal J, Nosko M, Yermakova T. Fitness - aerobic training of 15 - 17 years' age girl students, who have significant risk of deviations in backbone functional state. Journal of Human Sport and Exercise, 2017;12(4), 1289-1297. doi:10.14198/ jhse.2017.124.15

26.Kravchuk AI. Complex physical education of children of early and preschool age. Fizicheskaia kul'tura: vospitanie, obrazovanie, trenirovka, 2007;4:26-31. (in Russian)

27.Amosov NM. Meditation on health. Moscow: Physical Culture and Sport; 1987. (in Russian)

28. Voloshina LN, Kondakov VL, Tretyakov AA, Nikulina DE. Regulation of physical activity of preschool children. International Journal of Pharmacy and Technology, 2016;8(2):14275-14282.

29. Voloshina LN, Kondakov VL. Efficiency of pedagogical support of junior preschoolers' motor activity. Physical education: education, training, 2015; 5: 48-50.

30.Bytlykova AV. Organization and maintenance of physical education of children aged 4-6 in different age groups. Cand. Diss. Krasnodar; 2006. (in Russian)

31.Sidorov LK. Formation and realization of the motor need in the system of continuous physical education. Dokt. Diss. Krasnoyarsk; 2002. (in Russian)

32.Bernshtejn NA. Biomechanics and physiology of movements. Moscow: NPO "MODEK"; 1997. (in Russian)

33.Arshavskij IA. Physiological mechanisms and patterns of individual development. Moscow: Science; 1982. (in Russian)

34.Jagiełło M, Iermakov SS, Nowiński M. Differentiation of the somatic composition of students physical education specialising in various sports. Archives of Budo Science of Martial Arts and Extreme Sports. 2017;13:63-70.

35.Currie C et al. Social determinants of health and wellbeing among young people. Health Behaviour in School- 
aged Children (HBSC) study: international report from the 2009/2010 survey. (Health Policy for Children and Adolescents, No. 6). Copenhagen: WHO Regional Office for Europe; 2012.

36.Huhman ME, Potter LD, Duke JC, Judkins DR, Heitzler CD, Wong FL. Evaluation of a national physical activity intervention for children: VERB campaign, 2002-2004. Am J Prev Med, 2007 32:38-43.
37.Cieszczyk P, Zarebska A, Jastrzebski Z, Sawczyn M, Kozakiewicz-Drobnik I, Leonska-Duniec A, et al. Does the MTHFR A1298C Polymorphism Modulate the Cardiorespiratory Response to Training? Journal of Human Kinetics. 2016;54(1):43-53. doi:10.1515/hukin-2016-0055

38.Ulareanu M.V. Metode si tehnici de tonifiere a musculaturii [Methods and techniques of toning muscles]. Bucharest: Printech Publishing house; 2015. (In Romanian)

\section{Information about the authors:}

Voloshina L.N.; http://orcid.org/0000-0003-4373-1762; voloshina_I@bsu.edu.ru; Faculty of preschool, primary and special education, National Research University Belgorod State University; Pobeda 85, Belgorod, 308015, Russia.

Kondakov V.L. (Corresponding author) ; http://orcid.org/0000-0002-8094-0144; kondakov@bsu.edu.ru; Faculty of Physical Culture, National Research University Belgorod State University; Pobeda 85, Belgorod, 308015, Russia.

Tretyakov A.A.; http://orcid.org/0000-0001-7498-6675; tretyakov@bsu.edu.ru; Department of Physical Training, Putilin Belgorod Law Institute of Ministry of the Interior of Russia; ul. Gorkogo, 71, Belgorod, 308024, Russia.

Kopeikina E.N.; http://orcid.org/0000-0002-6027-3495; kopeikina@bsu.edu.ru; Faculty of Physical Culture, National Research University Belgorod State University; Pobeda 85, Belgorod, 308015, Russia.

Cretu Marian; http://orcid.org/0000-0003-1934-0534; marian.cretu@efsupit.ro; Faculty of Science, Physical Education and Informatics; University of Pitesti , Str. Targul din Vale, nr.1, 110040 Pitesti, Arges, Romania.

Potop Vladimir; http://orcid.org/0000-0001-8571-2469; vladimir_potop@yahoo.com; Faculty of Physical Education and Sport, Ecological University of Bucharest, Bulevardul General Vasile Milea 1G, București 061341, Romania.

Cite this article as: Voloshina LN, Kondakov VL, Tretyakov AA, Kopeikina EN, Cretu M, Potop V. Modern strategies for regulating the motor activity of preschool and school age children in the educational space. Pedagogics, psychology, medicalbiological problems of physical training and sports, 2018;22(2):114-119. doi:10.15561/18189172.2018.0208

The electronic version of this article is the complete one and can be found online at: http://www.sportpedagogy.org.ua/index.php/PPS/issue/archive

This is an Open Access article distributed under the terms of the Creative Commons Attribution License, which permits unrestricted use, distribution, and reproduction in any medium, provided the original work is properly cited (http://creativecommons.org/licenses/by/4.0/deed.en).

Received: 03.12.2017

Accepted: 30.12.2017; Published: 30.04.2018 